\title{
Clinical significance of androgen receptor and its phosphorylated form in breast cancer
}

\section{Dear Editor}

Attention to hormone receptor (HR) function in breast cancer has largely focused on estrogen receptor (ER), progesterone receptor (PgR), and human epidermal growth receptor 2 (HER2). The success of therapies targeted at these receptors has led to interest in androgen receptor (AR), a member of the steroid receptor (SR) subfamily, as another possible target in breast cancer therapy. Immunohistochemical studies have revealed an independent prognostic value of AR in ER $\alpha$-positive breast cancer (Castellano et al. 2010), and the prognosis of AR-positive/ER $\alpha$-negative tumors has been reported to be better than that of AR-negative one (Kuenen-Boumeester et al. 1996). These studies have revealed that AR plays an inherent role in breast cancer cell signaling. Much effort has been invested in elucidating the mechanism of action of AR in human epithelial cells. This includes research on posttranslational modifications, including phosphorylation, ubiquitination, acetylation, and sumoylation (Ward \& Weigel 2009). Among these, AR phosphorylation has been shown to play a critical role in signal transduction (Lin et al. 2001), and a large number of phosphorylation sites have been identified, with the majority near the N-terminus. AR is phosphorylated at serine-213/210 (pAR $\left.{ }^{213 / 210}\right)$ by the phosphatidylinositol 3-kinase/Akt signaling pathway (Wen et al. 2000), which modulates AR transcriptional activity (Lin et al. 2001, 2003). The objectives of the current study were to examine AR and $\mathrm{pAR}^{213 / 210}$ levels in a large series of breast cancers and to assess the impact of $\mathrm{AR}$ and $\mathrm{pAR}^{213 / 210}$ expression on relapsefree survival (RFS) and breast cancer-specific survival (BCSS) in all breast cancers.

A total of 379 consecutive patients (median age 58 years (range 21-93)) with invasive breast cancer were enrolled from a database that included patient and tumor characteristics, as well as the pathology findings at the initial and relapse diagnoses. All patients signed informed consent forms and were treated at the Department of Breast and Endocrine Surgery of our center in the period between 2001 and 2009. Patients were periodically examined at the Kumamoto University Hospital or affiliated hospitals. The median follow-up period was 66.1 months (range 0.23-145.1 months). AR was detected with mouse monoclonal AR-318 from Leica Biosystems (Newcastle, UK). Phospho-AR ${ }^{213 / 210}$ was detected with mouse monoclonal 156C135.2 from Abcam plc (Cambridge, UK). The levels of AR nuclear protein expression were determined in tissue samples of 379 consecutive female patients. In samples that showed detectable $\mathrm{AR}$, the levels of $\mathrm{pAR}^{213 / 210}$ nuclear and cytoplasmic expression were determined because $\mathrm{pAR}^{213 / 210}$ may be strongly stained even if AR staining is weak (Fig. 1A). All samples were scored using a histoscore (HS), multiplying the percentage (0-100) of cells stained at a given intensity by the staining intensity score (IS) ( 0 , none; 1 , weak; 2 , moderate; and 3 , intense). AR and nuclear and cytoplasmic expression of $\mathrm{pAR}^{213 / 210}$ were observed in benign breast tissue. However, the patterns of both AR and phosphorylated AR expression were increased in breast cancers compared with benign controls (Ren et al. 2013). Compared with other studies in which AR expression was dichotomized as having positive cells or not, we used a HS ( $>10)$ for AR and a IS $(\geq 2)$ for $\mathrm{pAR}^{213 / 210}$ as a cutoff point, which we believe more accurately reflects the expression of $\mathrm{AR}$ and its phosphorylation status in breast cancer (Fig. 1A).

The median HS was 126 in nuclear AR, 112 in nuclear $\mathrm{pAR}^{213 / 210}$, and zero in cytoplasmic $\mathrm{pAR}^{213 / 210}$ (Fig. 1B). Nuclear staining of AR was observed in $76 \%$ of the samples. The correlation of AR expression and patient characteristics is summarized in Table 1. Positive ARs were found in the groups of patients with lower nuclear grade $(P=0.0008)$, positive $\mathrm{ER} \alpha(P<0.0001)$, positive $\operatorname{PgR}$

Published by Bioscientifica Ltd. 
$(P<0.0001)$, positive ER $\beta \quad(P=0.0004)$, negative Ki-67 $(P=0.0036)$, and HR-positive/HER2-negative groups $(P<0.0001)$. The correlation between $\mathrm{pAR}^{213 / 210}$ nuclear and cytoplasmic expression and clinicopathological characteristics is shown in Table 2. Although there was no statistically significant difference between cytoplasmic $\mathrm{pAR}^{213 / 210}$ expression and clinicopathological parameters, positive nuclear $\mathrm{pAR}^{213 / 210}$ had a remarkable relationship with lower nuclear grade $(P=0.034)$, positive PgR $(P=0.035)$, and negative Ki-67 $(P=0.0004)$. Regarding treatments, breast-conserving surgery was more performed in AR-positive and nuclear pAR $^{213 / 210}$-positive patients $(P=0.023$ and $P=0.013$ respectively). As adjuvant therapy, AR-positive and nuclear $\mathrm{pAR}^{213 / 210}$-positive patients were more treated with endocrine therapy $(P=0.033$ and $P<0.0001$ respectively; Tables 1 and 2).

In the analysis of RFS, local recurrences and distant metastases were considered as an event. Forty-seven (12.4\%) patients experienced breast cancer relapse and $330(87.1 \%)$ were relapse free at the last follow-up. A total of 28 patients died of breast cancer, which were regarded as events when analyzing BCSS. AR-positive patients were associated with prolonged RFS $(P<0.0001)$ and BCSS $(P<0.0001)$ (Figs $2 \mathrm{~A}$ and $3 \mathrm{~A})$, which was tested by the
Kaplan-Meier method and verified by the log-rank (Mantel-Cox) test. Analyzed by subtype, AR positivity was associated with prolonged RFS and BCSS in the HR-positive/HER2-negative group $(P=0.020$ and $P=0.009$ respectively) and in the HR-negative/HER2negative group ( $P=0.016$ and $P=0.017$ respectively), but there was no statistical difference in survival associated with AR positivity in the HER2-positive group (Figs 2C, E, $\mathrm{G}$ and $3 \mathrm{C}, \mathrm{E}, \mathrm{G})$. Nuclear and cytoplasmic $\mathrm{pAR}^{213 / 210}$ were observed in $72.4 \%$ and $11.9 \%$, respectively, of the tested samples. Higher nuclear $\mathrm{pAR}^{213 / 210}$ expression was associated with prolonged RFS $(P=0.027)$ and BCSS $(P=0.0031)$ (Figs $2 \mathrm{~B}$ and $3 \mathrm{~B}$ ), but there was no statistically significant association of survival with $\mathrm{pAR}^{213 / 210}$ cytoplasmic expression (data not shown). Analyzed by subtype, higher nuclear $\mathrm{pAR}^{213 / 210}$ expression was associated with prolonged BCSS $(P=0.033)$, but not RFS $(P=0.51)$, in the HR-positive/HER2-negative group and with prolonged RFS $(P=0.030)$, but not BCSS $(P=0.21)$, in the HER2-positive group (Figs 2D, F and 3D, F). However, there was no statistically significant association between nuclear $\mathrm{pAR}^{213 / 210}$ and survival in the HR-negative/HER2-negative group (Figs $2 \mathrm{H}$ and $3 \mathrm{H}$ ) or between cytoplasmic $\mathrm{pAR}^{213 / 210}$ and survival in any subtype (data not shown). The RFS and BCSS Cox hazard analysis for total AR showed that AR
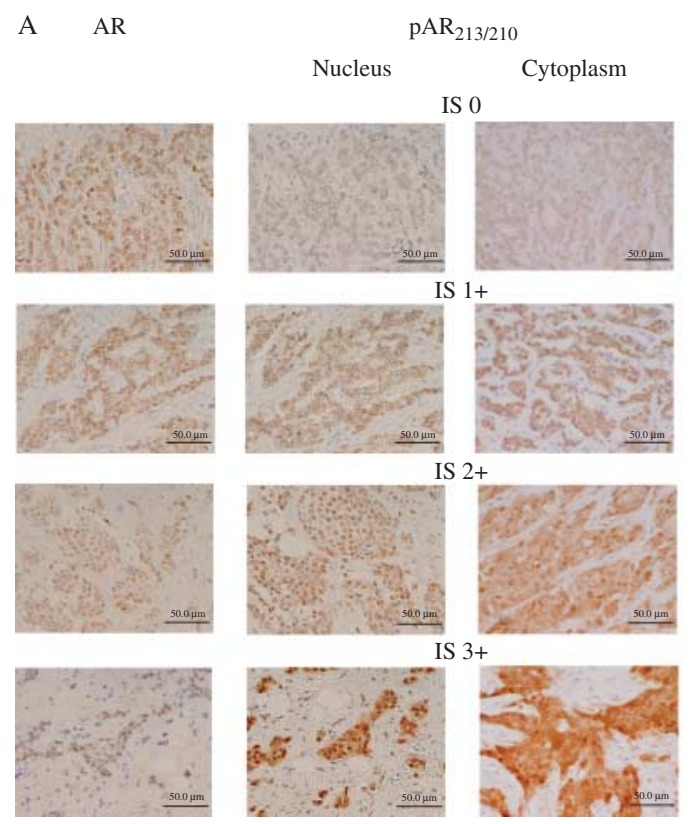

IS $2+$
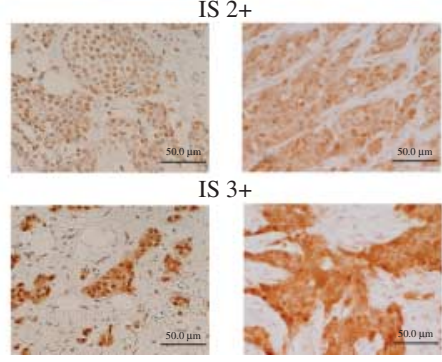

B

AR

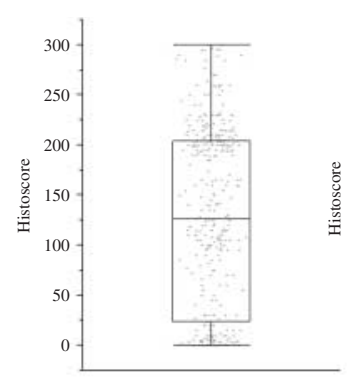

$\mathrm{pAR}_{213 / 210}$

Nucleus Cytoplasm
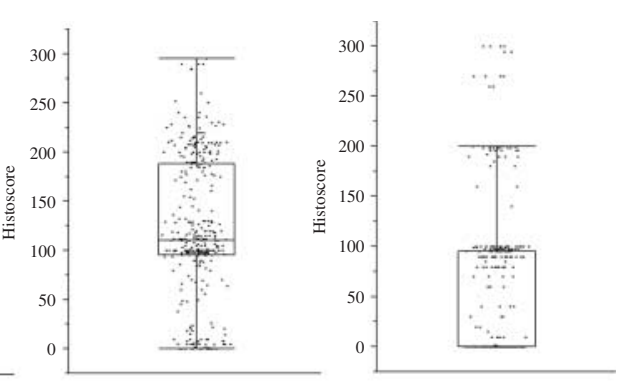

Figure 1

(A) Representative staining patterns of $p A R^{213 / 210}$ immunohistochemistry in the nucleus and in the cytoplasm: IS 0-3 (magnification $\times 40$ ). AR and $p A R^{213 / 210}$ in the nucleus are the same samples each. (B) The expression of AR, nuclear $P A R^{213 / 210}$, and cytoplasmic pAR ${ }^{213 / 210}$ depicted by box-plot.

http://erc.endocrinology-journals.org DOI: 10.1530/ERC-13-0317
(C) 2013 Society for Endocrinology Printed in Great Britain
Published by Bioscientifica Ltd 
Table 1 Correlation of AR expression with clinicopathological parameters

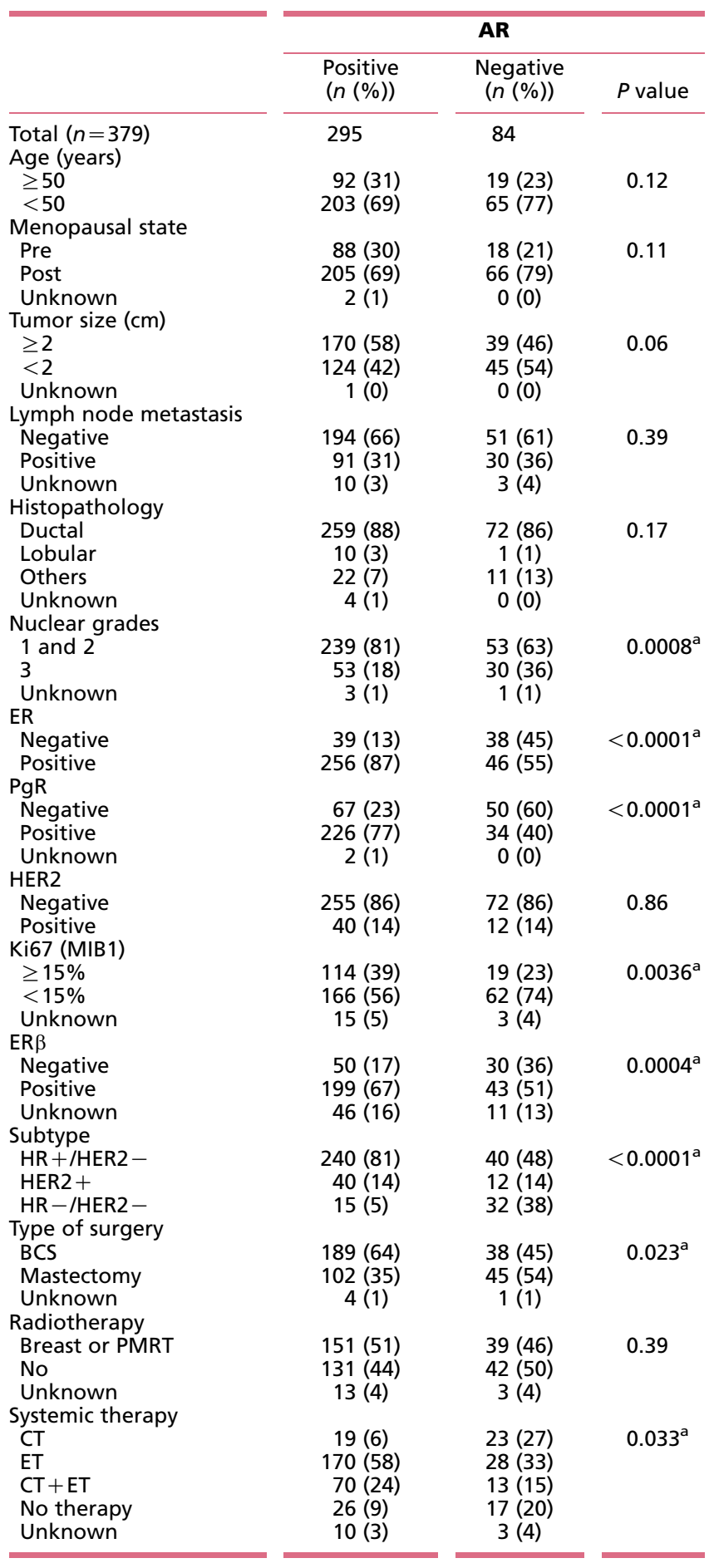

ER, estrogen receptor; PgR, progesterone receptor; HER2, human epidermal growth factor receptor 2; $A R$, androgen receptor; $B C S$, breastconserving surgery; PMRT, postmastectomy radiation therapy; $C T$, chemotherapy; ET, endocrine therapy; $\mathrm{HR}(+)$, estrogen receptor $(+)$ and/or progesterone receptor $(+)$. The $\chi^{2}$ test and Fisher's extract test were used to assess baseline differences between binary variables. $P<0.05$ is considered statistically significant.

${ }^{a}$ Factor showing statistical significance. could be a significant prognostic parameter for both RFS (univariate analysis (U), HR(95\% CI): $0.24(0.13-0.43), P<0.0001$ and multivariate analysis $(\mathrm{M})$, HR(95\% CI): $0.24(0.12-0.50), P<0.0001)$ and BCSS (U, HR(95\% CI): 0.13(0.05-0.28), $P<0.0001$ and M, HR(95\% CI): $0.28(0.10-0.70), P=0.0059)$ (Table 3$)$. The Cox hazards model analysis of AR-expressing cases is shown in Table 4. Higher nuclear $\mathrm{pAR}^{213 / 210}$ expression was a significant prognostic parameter for RFS (U, HR(95\% CI): $0.45(0.22-0.94), \quad P=0.035$ and $M, \operatorname{HR}(95 \% \quad \mathrm{CI})$ : $0.43(0.21-0.90), P=0.026)$ and for BCSS in univariate analysis (HR(95\% CI): 0.22(0.056-0.64), $P=0.005)$ but was a marginal relationship to BCSS in multivariate analysis $(P=0.078)$. Cytoplasmic expression of $\mathrm{pAR}^{213 / 210}$ was not a significant prognostic parameter for either RFS or BCSS.

Clinical and molecular studies involving $\mathrm{AR}$ in breast cancer over the past decade, and in particular over the last year, have reinvigorated interest. However, the role of the androgen-signaling pathway in breast cancer etiology and progression remains largely unknown. This is the first retrospective study to investigate the changes that occur to multiple members of the AR pathway in breast cancer, and in particular, to test whether phosphorylation of AR is associated with patient outcome measures. Site-specific phosphorylation of SRs has been shown to be modulated by a wide variety of kinases depending on the cellular context, affecting hormone sensitivity, receptor stability and localization, DNA binding, and cofactor interaction (Ward \& Weigel 2009). Phosphorylation of $\mathrm{AR}$ at serines 16, 81, 256, 308, 424, and 650 was reported to be increased in response to androgen, while serine 94 was constitutively phosphorylated (Gioeli et al. 2002, Black et al. 2004). AR phosphorylation is also induced by MAPK (serine-threonine kinase) and AKT, which sensitizes AR to low levels of DHT, allowing low levels of androgens, or alternative steroids, to induce translocation of the AR to the nucleus, facilitating gene activation. Of note, AKT can be activated via the PI3 kinase pathway, which is involved in cell growth, adhesion, and migration in many tumors (Lin et al. 2003) and specifically phosphorylates AR at Ser210 and Ser790 (Wen et al. 2000). In prostate cancer patients, $\mathrm{pAR}^{213 / 210}$ leads to the development of hormone refractory disease and worse outcomes (McCall et al. 2008). Although one group reported correlation between $\mathrm{pAR}^{213 / 210}$ and clinicopathological parameters in breast cancer (Ren et al. 2013), its significance as a prognostic marker remains unclear. Our data indicated that AR was a prognostic factor and the phosphorylated AR was strongly

Published by Bioscientifica Ltd. 
Table 2 Correlation of $p A R^{213 / 210}$ expression with clinicopathological parameters

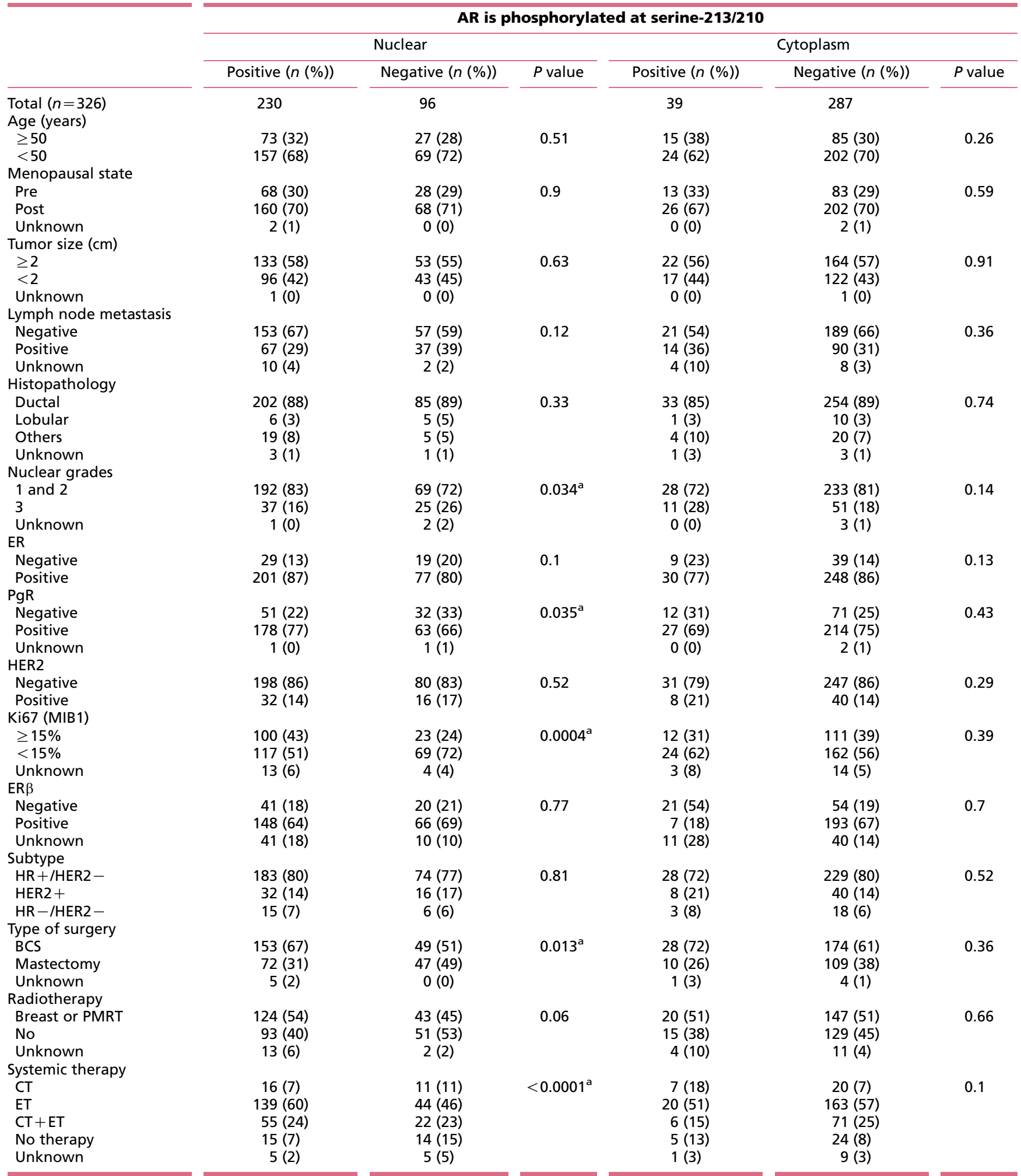

ER, estrogen receptor; PgR, progesterone receptor; HER2, human epidermal growth factor receptor 2; AR, androgen receptor; BCS, breast-conserving surgery; PMRT, postmastectomy radiation therapy; $C T$, chemotherapy; ET, endocrine therapy; $\mathrm{HR}(+)$, estrogen receptor $(+)$ and/or progesterone receptor $(+)$. The $\chi^{2}$ test and Fisher's extract test were used to assess baseline differences between binary variables. $P<0.05$ is considered statistically significant. ${ }^{a}$ Factor showing statistical significance. 
A

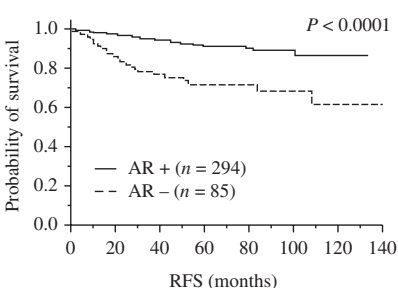

C

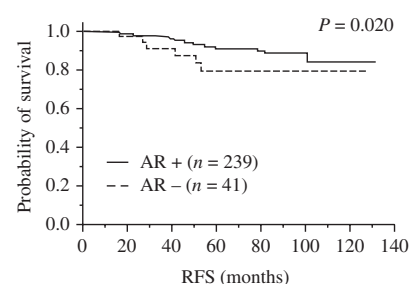

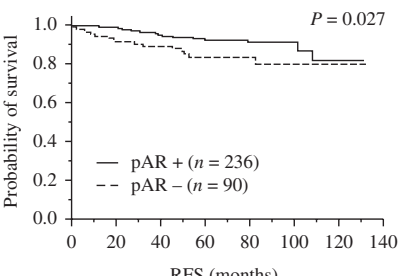

$\mathrm{D}$

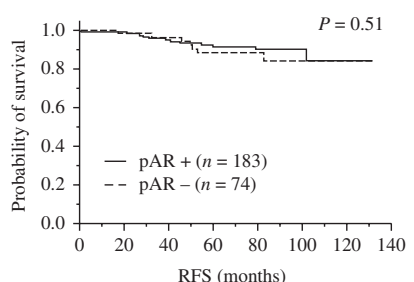

E

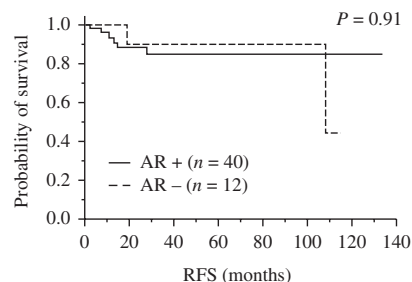

G

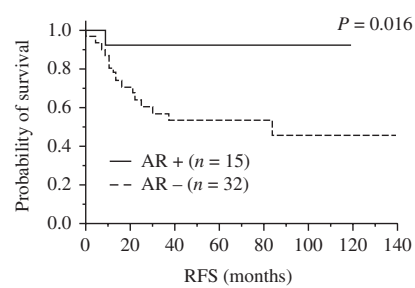

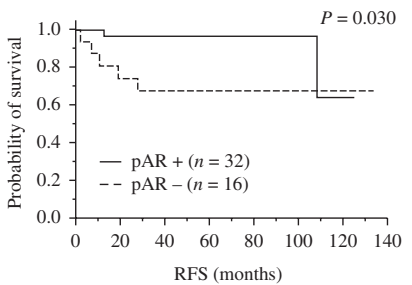

$\mathrm{H}$

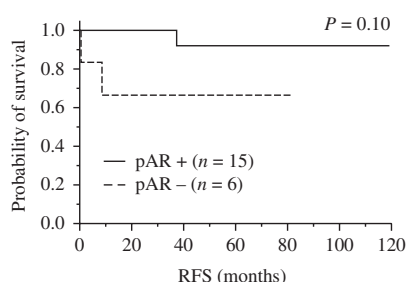

Figure 2

Kaplan-Meier plots illustrating the RFS of patients by total $A R(A)$, nuclear $p R^{213 / 210}(B)$, and total $A R(C, E$ and $G)$ and nuclear pAR ${ }^{213 / 210}(D, F$ and $H)$ expression levels in the HR-positive/HER2-negative group ( $C$ and $D$ ), the HER2-positive group (E and F), and the HR-negative/HER2-negative group

correlated with a better outcome in AR-positive patients. With more data regarding the presence of AR and AR signaling pathways in breast cancer, researchers have the opportunity to develop more efficacious targeted therapies.

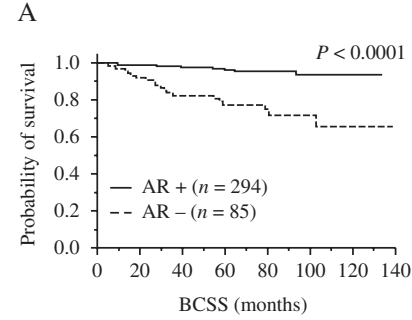

C

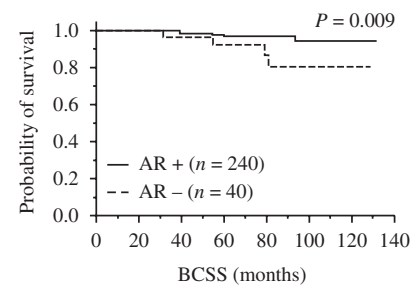

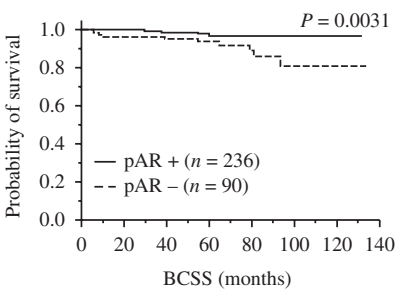

$\mathrm{D}$

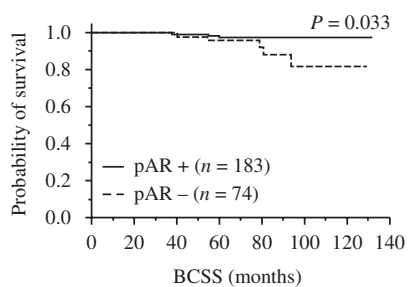

Figure 3

Kaplan-Meier plots illustrating the BCSS of patients by total $A R(A)$, nuclear $\operatorname{pAR}^{213 / 210}(\mathrm{~B})$, and total $A R(C, E$ and $G)$ and nuclear $p A R^{213 / 210}(D, F$ and $H)$ expression levels in the HR-positive/HER2-negative group ( $C$ and $D$ ), the

( $G$ and $H$ ) expression levels. For $A R, H S>10$ was considered positive, and $H S$ $\leq 10$ was considered negative. For $P A R^{213 / 210}, I S \geq 2$ was considered positive and IS $<2$ was considered negative. $p-A R, p A R^{213 / 210}$.

In conclusion, our study demonstrates that $\mathrm{AR}$ and $\mathrm{pAR}^{213 / 210}$ can be independent prognostic markers. Furthermore, further understanding of AR phosphorylation can provide new therapeutic targets in breast cancer.

$\mathrm{E}$
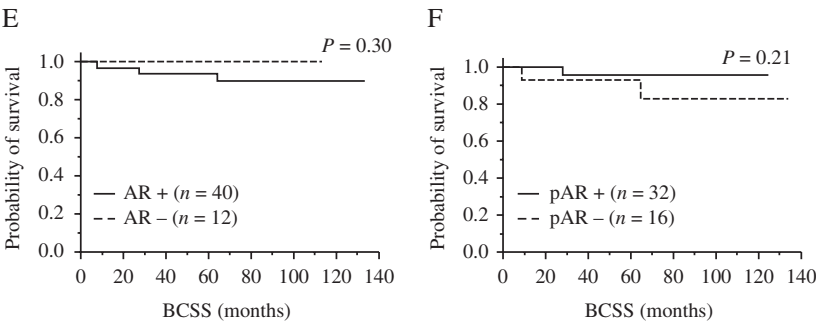

G

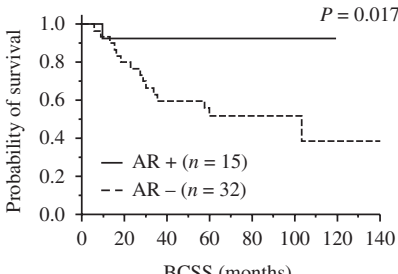

$\mathrm{H}$

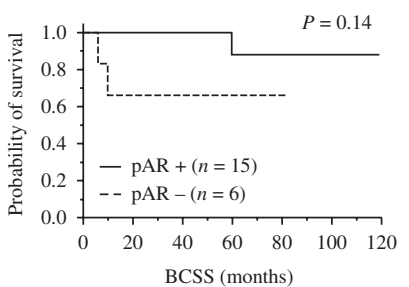

HER2-positive group ( $E$ and F), and the HR-negative/HER2-negative group ( $G$ and $H$ ) expression levels. AR and pAR ${ }^{213 / 210}$ cutoffs were the same as for (b). p-AR, pAR $213 / 210$

Published by Bioscientifica Ltd. 
Table 3 Univariate and multivariate analysis for RFS and BCSS in entire cohort (Cox proportional hazards model)

\begin{tabular}{|c|c|c|c|c|c|c|}
\hline \multirow[b]{2}{*}{ Variable } & \multirow[b]{2}{*}{ Value } & \multirow[b]{2}{*}{$\mathbf{n}$} & \multicolumn{2}{|l|}{ RFS } & \multicolumn{2}{|l|}{ BCSS } \\
\hline & & & $\mathrm{HR}(95 \% \mathrm{Cl})$ & $P$ value & $\mathrm{HR}(95 \% \mathrm{Cl})$ & $P$ value \\
\hline Age at operation ( $r e f=\leq 50)$ & $<50$ & 379 & $\begin{array}{l}0.54(0.30-0.98)(\mathrm{U}) / \\
0.37(0.19-0.75)(\mathrm{M})\end{array}$ & $\begin{array}{l}0.043(\mathrm{U}) * / \\
0.0067(\mathrm{M})\end{array}$ & $1.57(0.67-4.27)$ & NS \\
\hline Menopause state (ref=Pre) & Post & 377 & $0.69(0.38-1.28)$ & NS & $1.52(0.65-4.15)$ & NS \\
\hline T stage $(r e f=T 1)$ & $\leq \mathrm{T} 2$ & 378 & $\begin{array}{l}2.53(1.38-4.83)(\mathrm{U}) / \\
1.63(0.78-3.53)(\mathrm{M})\end{array}$ & $\begin{array}{l}0.0024(\mathrm{U}) / \\
0.18(\mathrm{M})\end{array}$ & $\begin{array}{l}3.68(1.64-9.37)(\mathrm{U}) / \\
1.46(0.51-4.51)(\mathrm{M})\end{array}$ & $\begin{array}{l}0.0012(\mathrm{U}) / \\
0.48(\mathrm{M})\end{array}$ \\
\hline Node metastasis $(r e f=0)$ & Positive & 366 & $\begin{array}{l}2.32(1.27-4.27)(\mathrm{U}) / \\
2.11(1.06-4.29)(\mathrm{M})\end{array}$ & $\begin{array}{l}0.006(\mathrm{U}) * / \\
0.032(\mathrm{M})\end{array}$ & $\begin{array}{l}3.94(1.81-9.22)(\mathrm{U}) / \\
3.33(1.34-9.20)(\mathrm{M})\end{array}$ & $\begin{array}{l}0.0005(\mathrm{U}) * / \\
0.008(\mathrm{M})\end{array}$ \\
\hline Histopathology (ref = Lobular) & Ductal & 342 & $0.62(0.19-3.83)$ & NS & $0.33(0.09-2.12)$ & NS \\
\hline Nuclear grades (ref $=1$ and 2$)$ & 3 & 375 & $\begin{array}{l}3.05(1.66-5.53)(\mathrm{U}) / \\
1.96(0.92-4.16)(\mathrm{M})\end{array}$ & $\begin{array}{l}0.0005(\mathrm{U}) / \\
0.079(\mathrm{M})\end{array}$ & $\begin{array}{l}4.09(1.91-8.83)(\mathrm{U}) / \\
1.46(0.62-3.55)(\mathrm{M})\end{array}$ & $\begin{array}{l}0.0004(\mathrm{U}) / \\
0.17(\mathrm{M})\end{array}$ \\
\hline $\mathrm{ER} \alpha(\mathrm{IHC})(\mathrm{ref}=<1 \%)$ & $\leq 1 \%$ & 379 & $\begin{array}{l}0.29(0.16-0.54)(\mathrm{U}) / \\
0.48(0.21-1.08)(\mathrm{M})\end{array}$ & $\begin{array}{l}0.0001(\mathrm{U}) / \\
0.078(\mathrm{M})\end{array}$ & $\begin{array}{l}0.11(0.04-0.24)(\mathrm{U}) / \\
0.23(0.07-0.63)(\mathrm{M})\end{array}$ & $\begin{array}{c}<0.0001(\mathrm{U})^{*} / \\
0.0045(\mathrm{M})\end{array}$ \\
\hline $\operatorname{PgR}(\mathrm{IHC})(\mathrm{ref}=<1 \%)$ & $\leq 1 \%$ & 377 & $0.39(0.22-0.71)$ & 0.002 & $0.12(0.04-0.28)$ & $<0.0001$ \\
\hline HER2 (ref= Negative) & Positive & 379 & $1.09(0.44-2.30)$ & NS & $0.68(0.16-1.95)$ & NS \\
\hline Ki-67 (MIB1) $(r e f=<15 \%)$ & $<15$ & 361 & $\begin{array}{l}2.63(1.28-6.10)(\mathrm{U}) / \\
1.56(0.70-3.95)(\mathrm{M})\end{array}$ & $\begin{array}{l}0.0067(\mathrm{U}) / \\
0.28(\mathrm{M})\end{array}$ & $\begin{array}{l}7.23(2.17-45.2)(\mathrm{U}) / \\
3.05(0.88-19.1)(\mathrm{M})\end{array}$ & $\begin{array}{l}0.0003(\mathrm{U}) / \\
0.08(\mathrm{M})\end{array}$ \\
\hline$A R(r e f=\leq H S 10)$ & $<\mathrm{HS} 10$ & 379 & $\begin{array}{l}0.24(0.13-0.43)(\mathrm{U}) \\
0.24(0.12-0.50)(\mathrm{M})\end{array}$ & $\begin{array}{l}<0.0001(\mathrm{U})^{* /} \\
<0.0001(\mathrm{M})\end{array}$ & $\begin{array}{l}0.13(0.05-0.28)(\mathrm{M}) / \\
0.28(0.10-0.70)\end{array}$ & $\begin{array}{c}<0.0001(\mathrm{U})^{*} / \\
0.0059(\mathrm{M})\end{array}$ \\
\hline $\operatorname{Er} \beta$ (ref $=$ the 25 th percentile) & Positive & 322 & $1.27(0.62-2.87)$ & NS & $1.04(0.45-2.69)$ & NS \\
\hline Systemic therapy $(\mathrm{ref}=\mathrm{No})$ & Yes & 366 & $0.57(0.26-1.41)$ & NS & $0.39(0.16-1.08)$ & NS \\
\hline
\end{tabular}

ER, estrogen receptor; PgR, progesterone receptor; HER2, human epidermal growth factor receptor 2; AR, androgen receptor; RFS, relapse-free survival; BCSS, breast cancer-specific survival; HR, hazard ratio; NS, not significant; U, univariate analysis; M, multivariate analysis. *It was also significant in univariate and multivariate analyses. $P<0.05$ is considered statistically significant.

Table 4 Univariate and multivariate analysis for RFS in AR-positive (Cox proportional hazards model)

\begin{tabular}{|c|c|c|c|c|c|c|}
\hline \multirow[b]{2}{*}{ Variable } & \multirow[b]{2}{*}{ Value } & \multirow[b]{2}{*}{$\mathbf{n}$} & \multicolumn{2}{|l|}{ RFS } & \multicolumn{2}{|l|}{ BCSS } \\
\hline & & & HR $(95 \% \mathrm{Cl})$ & $P$ value & HR $(95 \% \mathrm{Cl})$ & $P$ value \\
\hline Age at operation (ref $=\leq 50$ ) & $<50$ & 326 & $\begin{array}{l}0.35(0.17-0.72)(U) / \\
0.40(0.19-0.83)(\mathrm{M})\end{array}$ & $\begin{array}{l}0.0047(\mathrm{U}) * / \\
0.014(\mathrm{M})\end{array}$ & $1.10(0.36-4.01)$ & NS \\
\hline Menopause state (ref $=$ Pre) & Post & 324 & $0.53(0.26-1.11)$ & 0.09 & $1.10(0.37-4.03)$ & NS \\
\hline T stage $(r e f=T 1)$ & $\leq \mathrm{T} 2$ & 325 & $\begin{array}{l}2.29(1.10-4.98)(\mathrm{U}) / \\
2.03(0.97-4.44)(\mathrm{M})\end{array}$ & $\begin{array}{l}0.025(\mathrm{U}) / \\
0.058(\mathrm{M})\end{array}$ & $\begin{array}{l}4.79(1.49-21.2)(\mathrm{U}) / \\
1.83(0.45-9.35)(\mathrm{M})\end{array}$ & $\begin{array}{l}0.0071(\mathrm{U}) / \\
0.40(\mathrm{M})\end{array}$ \\
\hline Node metastasis $(r e f=0)$ & Positive & 314 & $1.96(0.92-4.15)$ & 0.077 & $\begin{array}{l}4.31(1.40-15.9)(\mathrm{U}) / \\
2.67(0.73-11.4)(\mathrm{M})\end{array}$ & $\begin{array}{l}0.010(\mathrm{U}) / \\
0.13(\mathrm{M})\end{array}$ \\
\hline Histopathology (ref = Lobular) & Ductal & 298 & $0.50(0.15-3.16)$ & NS & $0.20(0.05-1.34)$ & NS \\
\hline Nuclear grades (ref $=1$ and 2 ) & 3 & 323 & $2.21(0.99-4.62)$ & 0.051 & $2.32(0.71-6.73)$ & NS \\
\hline $\mathrm{ER} \alpha(\mathrm{IHC})(\mathrm{ref}=<1 \%)$ & $\leq 1 \%$ & 326 & $0.59(0.26-1.50)$ & NS & $\begin{array}{l}0.23(0.082-0.72)(\mathrm{U}) / \\
0.26(0.08-0.87)(\mathrm{M})\end{array}$ & $\begin{array}{l}0.013(\mathrm{U}) * / \\
0.03(\mathrm{M})\end{array}$ \\
\hline $\operatorname{PgR}(\mathrm{IHC})(\mathrm{ref}=<1 \%)$ & $\leq 1 \%$ & 324 & $0.89(0.42-2.05)$ & NS & $0.27(0.09-0.79)$ & 0.0182 \\
\hline HER2 (ref= Negative) & Positive & 326 & $1.70(0.67-3.74)$ & NS & $1.46(0.32-4.67)$ & NS \\
\hline Ki-67 (MIB1) $($ ref $=<15 \%)$ & $<15$ & 309 & $2.02(0.90-5.12)$ & 0.08 & $\begin{array}{l}3.75(1.02-24.1)(\mathrm{U}) / \\
1.54(0.36-10.6)(\mathrm{M})\end{array}$ & $\begin{array}{l}0.045(\mathrm{U}) / \\
0.58(\mathrm{M})\end{array}$ \\
\hline $\begin{array}{l}\operatorname{Er} \beta \text { (ref =the 25th percentile) } \\
\operatorname{pAR}^{213 / 210}\end{array}$ & Positive & 275 & $1.82(0.68-6.27)$ & NS & $1.63(0.43-10.7)$ & NS \\
\hline In the nucleus (ref $=<$ IS 2 ) & Positive & 326 & $\begin{array}{l}0.45(0.22-0.94)(\mathrm{U}) / \\
0.43(0.21-0.90)(\mathrm{M})\end{array}$ & $\begin{array}{l}0.035(\mathrm{U}) * / \\
0.026(\mathrm{M})\end{array}$ & $\begin{array}{l}0.22(0.056-0.64)(U) / \\
0.32(0.08-1.13)(\mathrm{M})\end{array}$ & $\begin{array}{l}0.005(\mathrm{U}) / \\
0.078(\mathrm{M})\end{array}$ \\
\hline In the cytoplasm $(r e f=<$ IS 2$)$ & Positive & 326 & $1.54(0.52-3.72)$ & NS & $0.59(0.03-2.98)$ & NS \\
\hline Systemic therapy $(r e f=$ No) & Yes & 316 & $0.72(0.25-3.04)$ & NS & $0.45(0.12-2.97)$ & NS \\
\hline
\end{tabular}

ER, estrogen receptor; PgR, progesterone receptor; HER2, human epidermal growth factor receptor 2; AR, androgen receptor; RFS, relapse-free survival $\mathrm{HR}$, hazard ratio; NS, not significant; $U$, univariate analysis; $M$, multivariate analysis. *It was also significance in univariate and multivariate analysis. $P<0.05$ is considered statistically significant.

http://erc.endocrinology-journals.org DOI: $10.1530 /$ ERC-13-0317
(C) 2013 Society for Endocrinology Printed in Great Britain
Published by Bioscientifica Ltd. 
Takashi Takeshita $^{1}$ Yoko Omoto $^{1}$ Mutsuko Yamamoto-Ibusuki ${ }^{1}$ Yutaka Yamamoto $^{2}$ Hirotaka Iwase $^{1}$

${ }^{1}$ Department of Breast and Endocrine Surgery, Graduate School of Medical Sciences, Kumamoto University, 1-1-1 Honjo, Chuo-ku, Kumamoto, 860-8556, Japan ${ }^{2}$ Department of Molecular-Targeting Therapy for Breast Cancer, Kumamoto University Hospital, 1-1-1 Honjo, Chuo-ku, Kumamoto, 860-8556, Japan

(Correspondence should be addressed to H Iwase); email: hiwase@kumamoto-u.ac.jp

\section{Declaration of interest}

The authors declare that there is no conflict of interest that could be perceived as prejudicing the impartiality of the research reported.

\section{Funding}

Supported by a grant-in-aid (project no. 2459191000) for Scientific Research from the Ministry of Education, Science, and Culture of Japan.

\section{Author contribution statement}

The study was conceived by T Takeshita and H Iwase. T Takeshita generated and assembled the data. T Takeshita, Y Omoto, M Yamamoto-Ibusuki, $\mathrm{Y}$ Yamamoto, and $\mathrm{H}$ Iwase developed and performed the data analysis and wrote the manuscript.

\section{Acknowledgements}

The authors wish to thank Ms Yuki Azakami for her excellent technical support.

\section{References}

Black BE, Vitto MJ, Gioeli D, Spencer A, Afshar N, Conaway MR, Weber MJ \& Paschal BM 2004 Transient, ligand-dependent arrest of the androgen receptor in subnuclear foci alters phosphorylation and coactivator interactions. Molecular Endocrinology 18 834-850. (doi:10.1210/me. 2003-0145)

Castellano I, Allia E, Accortanzo V, Vandone AM, Chiusa L, Arisio R, Durando A, Donadio M, Bussolati G, Coates AS et al. 2010 Androgen receptor expression is a significant prognostic factor in estrogen receptor positive breast cancers. Breast Cancer Research and Treatment 124 607-617. (doi:10.1007/s10549-010-0761-y)

Gioeli D, Ficarro SB, Kwiek JJ, Aaronson D, Hancock M, Catling AD, White FM, Christian RE, Settlage RE, Shabanowitz J et al. 2002 Androgen receptor phosphorylation. Regulation and identification of the phosphorylation sites. Journal of Biological Chemistry 277 29304-29314. (doi:10.1074/jbc. M204131200)

Kuenen-Boumeester V, Van der Kwast TH, Claassen CC, Look MP, Liem GS, Klijn JG \& Henzen-Logmans SC 1996 The clinical significance of androgen receptors in breast cancer and their relation to histological and cell biological parameters. European Journal of Cancer $\mathbf{3 2 \mathbf { A }}$ 1560-1565. (doi:10.1016/0959-8049(96)00112-8)

Lin HK, Yeh S, Kang HY \& Chang C 2001 Akt suppresses androgen-induced apoptosis by phosphorylating and inhibiting androgen receptor. PNAS 98 7200-7205. (doi:10.1073/pnas.121173298)

Lin HK, Hu YC, Yang L, Altuwaijri S, Chen YT, Kang HY \& Chang C 2003 Suppression versus induction of androgen receptor functions by the phosphatidylinositol 3-kinase/Akt pathway in prostate cancer LNCaP cells with different passage numbers. Journal of Biological Chemistry $\mathbf{2 7 8}$ 50902-50907. (doi:10.1074/jbc.M300676200)

McCall P, Gemmell LK, Mukherjee R, Bartlett JM \& Edwards J 2008 Phosphorylation of the androgen receptor is associated with reduced survival in hormone-refractory prostate cancer patients. British Journal of Cancer 98 1094-1101. (doi:10.1038/sj.bjc.6604152)

Ren Q, Zhang L, Ruoff R, Ha S, Wang J, Jain S, Reuter V, Gerald W, Giri DD, Melamed J et al. 2013 Expression of androgen receptor and its phosphorylated forms in breast cancer progression. Cancer 119 2532-2540. (doi:10.1002/cncr.28092)

Ward RD \& Weigel NL 2009 Steroid receptor phosphorylation: assigning function to site-specific phosphorylation. Biofactors 35 528-536. (doi:10.1002/biof.66)

Wen Y, Hu MC, Makino K, Spohn B, Bartholomeusz G, Yan DH \& Hung MC 2000 HER-2/neu promotes androgen-independent survival and growth of prostate cancer cells through the Akt pathway. Cancer Research 60 6841-6845.

Received in final form 15 August 2013

Accepted 19 August 2013

Made available online as an Accepted Preprint

22 August 2013 http://erc.endocrinology-journals.org DOI: 10.1530/ERC-13-0317
(C) 2013 Society for Endocrinology Printed in Great Britain
Published by Bioscientifica Ltd. 